\title{
Regulation of Enzyme Synthesis and Variation of Residual Methanol Concentration during Carbon-limited Growth of Kloeckera sp. 2201 on Mixtures of Methanol and Glucose
}

\author{
By Th. EGLI, $\dagger$ N. D. LINDLEY $\ddagger$ AND J. R. QUAYLE* \\ Department of Microbiology, The University, Sheffield S10 2TN, U.K.
}

(Received 8 December 1982)

\begin{abstract}
The methylotrophic yeast Kloeckera sp. 2201 was grown in double carbon (glucose/methanol) limitation in a chemostat at a constant dilution rate and the regulation of the synthesis of enzymes involved in the assimilation of methanol and the breakdown of glucose was studied as a function of the composition of the glucose/methanol mixture in the inflowing medium. Enhanced synthesis of most of the enzymes taking part in the assimilation of $\mathrm{C}_{1}$ units took place despite the presence of glucose in the medium. Depending on the enzyme, 40 to $60 \% \mathrm{w} / \mathrm{w}$ of total substrate) methanol in the mixture was enough to cause maximal induction and no further enhancement of their specific activities was observed during growth on mixtures containing higher methanol/glucose ratios. The only two enzymes involved in the assimilation of methanol not showing these characteristic patterns were 'classical' transketolase and transaldolase. Substrate fluxes through the individual steps of glucose and methanol metabolism have been calculated and compared with the experimentally determined specific activities of the enzymes concerned. The three enzymes whose specific activities were least in excess of the substrate flux calculated to be catalysed by them were transketolase, transaldolase and (possibly) dihydroxyacetone synthase.

The residual concentration of methanol was measured in the culture as a function of the composition of the supplied glucose/methanol mixture. During growth with mixtures the concentration of methanol was always lower than during growth with this substrate as the only carbon source. Possible ecological advantages accruing to a facultative methylotroph as a consequence of this behaviour are discussed.
\end{abstract}

\section{INTRODUCTION}

It has now been established that assimilation of methanol by methylotrophic yeasts occurs via the xylulose monophosphate (XuMP) cycle of formaldehyde fixation, also referred to as the dihydroxyacetone (DHA) pathway (van Dijken et al., 1978; Babel \& Loffhagen, 1979; O'Connor \& Quayle, 1979; Kato et al., 1979; Waites \& Quayle, 1980; Lindley et al., 1980; Waites et al., 1981). With the cycle established it is clearly of interest to study its regulation. Operation of the XuMP cycle requires the synthesis of two key assimilatory enzymes specific to the cycle, namely DHA synthase and DHA kinase, whereas the remaining enzymes of the cycle are common to the classical pentose phosphate cycle, glycolysis and/or gluconeogenesis.

† Present address: Eidgenössische Anstalt für Wasserversorgung, Abwasserreinigung und Gewässerschutz, Überlandstrasse 133, CH-8600 Dübendorf, Switzerland.

$\ddagger$ Present address: Department of Microbiology, University of Reading, Reading RG1 5AQ, U.K.

Abbreviations. $\mathrm{C}_{1}$, methanol; $\mathrm{C}_{6}$, glucose $; D$, dilution rate $\left(\mathrm{h}^{-1}\right) ; K_{\mathrm{s}}$, saturation constant $\left(\mathrm{mg} 1^{-1}\right) ; q_{\mathrm{m}}$, maximal specific rate of substrate consumption [g substrate (g biomass) $)^{-1} \mathrm{~h}^{-1}$ ]; $q_{\mathrm{s}}, q_{\mathrm{C} 1}$, specific rate of substrate or methanol consumption respectively [g substrate (g biomass) $)^{-1} \mathrm{~h}^{-1}$ ]; $s$, residual substrate concentration in the culture liquid $\left(\mathrm{g} \mathrm{l}^{-1}\right), s_{0}$, concentration of substrate in the inflowing medium $\left(\mathrm{g} \mathrm{l}^{-1}\right) ; x$, concentration of biomass $\left(\mathrm{g} \mathrm{l}^{-1}\right)$; DHA, dihydroxyacetone; XuMP, xylulose 5-phosphate; EMP, Embden-Meyerhof-Parnas. 


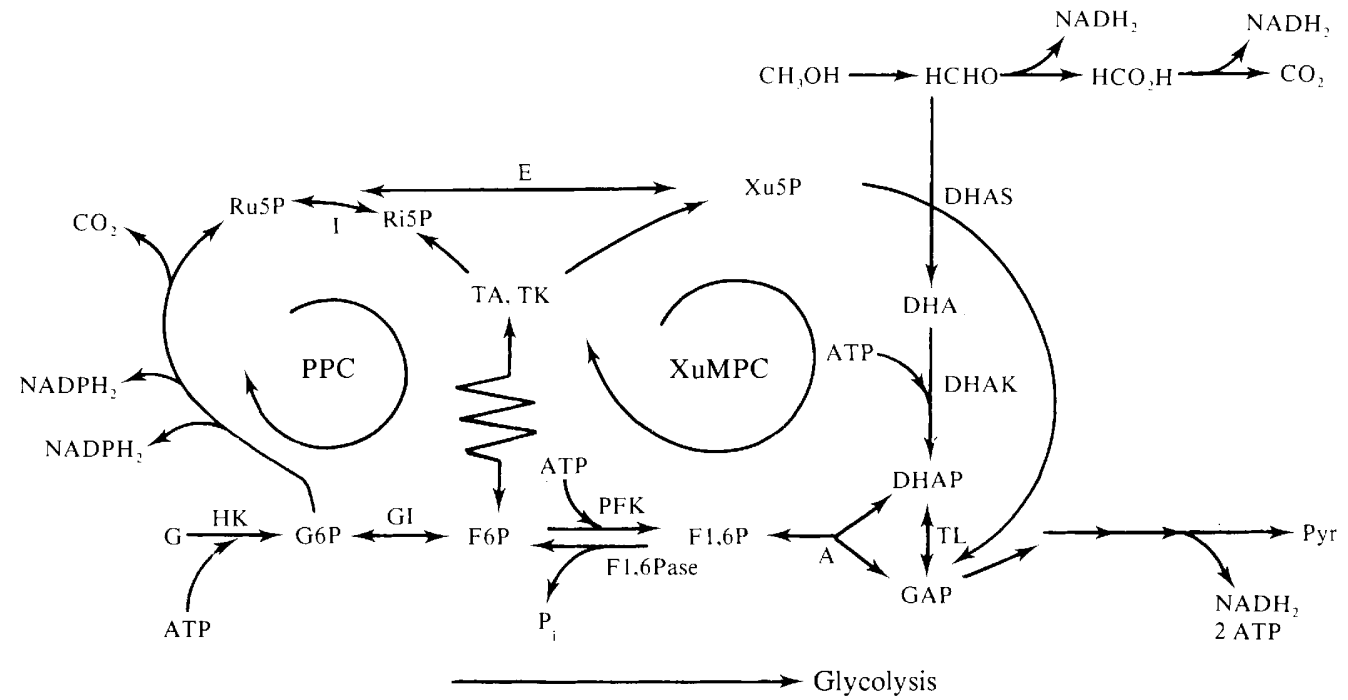

Gluconeogenesis

Fig. 1. Interrelation between metabolic pathways of glucose and methanol in methylotrophic yeasts. A, aldolase: DHAK, dihydroxyacetone kinase; DHA(P), dihydroxyacetone (phosphate); DHAS, dihydroxyacetone synthase: E, ribulose-5-phosphate epimerase; F6P, fructose 6-phosphate: F1,6P, fructose 1,6-bisphosphate; F1,6Pase, fructose-1,6-bisphosphatase; G, glucose; GAP, glyceraldehyde 3phosphate; GI, glucose-6-phosphate isomerase; G6P, glucose 6-phosphate; HK, hexokinase; I, ribose5-phosphate isomerase; PFK, phosphofructokinase; PPC, pentose phosphate cycle; Pyr, pyruvate; Ri5P, ribose 5-phosphate; Ru5P, ribulose 5-phosphate; TA, transaldolase; TI, triosephosphate isomerase: TK, transketolase; Xu5P, xylulose 5-phosphate; XuMPC, xylulose monophosphate cycle. The carbon flows through the pathways are indicated by arrows.

It was recently reported that methylotrophic yeasts could grow on mixtures of sorbitol or glucose and methanol under carbon limitation in the chemostat (Eggeling \& Sahm, 1980; 1981; Egli \& Käppeli, 1980; Egli et al., 1982a, b); it was shown that under such conditions both substrates were assimilated simultaneously. Growth on mixtures of glucose and methanol sets an unusual regulatory problem to such organisms: whereas glucose has to be broken down via glycolysis and/or the oxidative pentose phosphate cycle to produce $\mathrm{C}_{3}$ units for assimilation and dissimilation, the assimilatory flux of carbon derived from methanol via the XuMP cycle goes in the reverse direction (see Fig. 1). Theoretically the acceptor molecule, XuMP, for the fixation of formaldehyde could be supplied directly by enzymic degradation of glucose via the pentose phosphate cycle, thus obviating the necessity for its cyclic regeneration via the XuMP cycle (at least up to equimolar mixtures of methanol to glucose). With respect to the dissimilation of methanol it is theoretically possible that formaldehyde carbon, after incorporation into sugar phosphates via the XuMP cycle, could ultimately be oxidized via the tricarboxylic acid cycle thus making the two dehydrogenases for formaldehyde and formate superfluous. Growth in chemostat culture at a constant dilution rate with different mixtures of glucose and methanol, as described by Egli et al. (1982a), offers a suitable system for investigating the regulation of the synthesis of enzymes involved in these interlocking pathways.

Egli et al. (1982a) reported that under such growth conditions the specific activities of methanol-dissimilating enzymes changed as a function of the composition of the supplied glucose/methanol mixture. This regulation of enzyme synthesis at a constant growth rate implies changes in the actual substrate concentrations in the culture. Therefore the predictions of the Monod model that a constant growth rate implies a constant concentration of the (single) limiting substrate is probably not valid for dual (or multiple) substrate-limited growth. However, since few examples of multiple substrate-limited growth are known (for a summary see Harder \& Dijkhuizen, 1976; Bull \& Brown, 1979; Harder \& Dijkhuizen, 1982) it is not surprising that the kinetics of multiple substrate-limited growth are usually only speculated about (e.g. Bailey \& Ollis, 1977). A first approach to investigating the kinetics of mixed substrate growth is to 
estimate residual substrate concentrations at a constant dilution rate as a function of the composition of the limiting substrate mixture.

This paper records a study of growth of Kloeckera sp. 2201 [now classified as Candida boidinii according to Lee \& Komagata (1980)] in a chemostat at a constant dilution rate as a function of the composition of the supplied glucose/methanol mixture in order to investigate the effects of the dual substrates on the regulation of assimilatory enzymes and the kinetics of mixed substrate-limited growth.

\section{METHODS}

Organism and cultization. Kloeckera sp. 2201 was cultivated under carbon-limited chemostat conditions on a synthetic medium containing glucose, methanol or glucose/methanol mixtures as described previously (Fgli, 1980; Egli \& Fiechter, 1981). The total amount of carbon (whether from glucose and/or methanol) in the inflowing medium varied between 2 and $4 \mathrm{~g} \mathrm{l}^{-1}$ in different experiments; the composition of mixed substrates is expressed in terms of percentage $(w / w)$ of each component. The growth temperature was $30^{\circ} \mathrm{C}$ and the $\mathrm{pH}$ was controlled at 5.0 by automatic addition of $3 \mathrm{M}-\mathrm{NaOH}$. The dissolved oxygen tension was always higher than $50 \%$ air saturation.

Preparation of cell-free extracts. Cells were collected from the chemostat outlet and immediately cooled to 0 " $\mathrm{C}$ : they were centrifuged and washed once with $50 \mathrm{~mm}$-potassium phosphate buffer $\mathrm{pH} 7.0$ at $4{ }^{\circ} \mathrm{C}$. Cell paste $(1 \mathrm{~g}$ wet weight) was resuspended in $4 \mathrm{ml} 100 \mathrm{~mm}$-potassium phosphate buffer $\mathrm{pH} 7 \cdot 0$, glass beads $(1 \mathrm{~g}, 40 \mathrm{mesh})$ were added and the cells were broken by ultrasonication (MSE model $150 \mathrm{~W}$ ) at $0{ }^{\circ} \mathrm{C}$ for $5 \mathrm{~min}$ with $1 \mathrm{~min}$ intervals. The supernatant after centrifugation at $20000 \mathrm{~g}$ for $20 \mathrm{~min}$ at 4 C contained $8-14 \mathrm{mg}^{2}$ protein $\mathrm{ml}^{-1}$ and was used for all enzyme assays.

Enzlme assays. All assays were carried out at $30^{\circ} \mathrm{C}$ using a Pye Unicam SP8-400 spectrophotometer. DHA synthase and transketolase (EC 2.2.1.1) were assayed according to Waites \& Quayle (1981). DHA kinase, fructose-1,6-bisphosphate aldolase (EC 4.1.2.13) and phosphofructokinase (EC 2.7.1.11) were assayed as described by van Dijken et al. (1978). The assay for fructose-1,6-bisphosphatase (EC 3.1.3.11) was described by van Dijken \& Quayle (1977). The assays of Wood (1970) were used to measure the specific activities of ribose-5phosphate isomerase (EC 5.3.1.6) and ribulose-5-phosphate 3-epimerase (EC 5.1.3.1). Transaldolase (EC 2.2.1.2) was assayed by the method of Tchola \& Horecker (1966). 3-Phosphoglycerate kinase (EC 2.7.2.3) was assayed according to von Meyenburg (1969). The method of Bücher \& Pfleiderer (1955) was used to assay for pyruvate kinase (EC 2,7.1.40).

The assay for glucose-6-phosphate isomerase (EC 5.3.1.9) contained, per $\mathrm{ml}$ : Tris buffer $\mathrm{pH} 8 \cdot 0,100 \mu \mathrm{mol}$; fructose 6-phosphate, $1.7 \mu \mathrm{mol}$; NADP, $0.5 \mu \mathrm{mol}$; glucose-6-phosphate dehydrogenase (Boehringer, Grade II from yeast, phosphoglucoisomerase-free), 1.7 units: and extract. The reaction was started by adding extract.

Enzlme units. For all enzymes the specific activities are expressed as the rate of substrate consumption (or

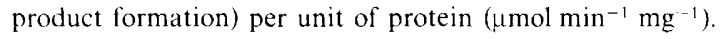

Protein assay. The method of Lowry was used to determine the protein concentration in cell-free extracts. Bovine serum albumin (Armour, Eastbourne, U.K.) was used as standard.

Substrate concentrations. Samples of $2-3 \mathrm{ml}$ for the estimation of the residual concentrations of glucose and methanol in the culture liquid were withdrawn from the fermenter and immediately filtered through a membrane filter. In order to achieve rapid separation of the cells from the culture liquid the following sampling method was developed. A reduced-pressure Pyrex filtering device ( $4.5 \mathrm{~cm}$ diameter: Millipore catalogue no. XX 1004720) was fitted with a membrane filter (Sartorius, $0.2 \mu \mathrm{m}$, regenerated cellulose, resistant to methanol and autoclavable) and a glass fibre prefilter. Both filters were prewetted with distilled water; superfluous water was removed from the filters with absorbent paper followed by sucking air through the filters. For the actual sampling, suction was applied to the filtering device and a sample (approximately $2 \mathrm{ml}$ ) was diverted from the out flow of the chemostat directly on to the membrane filter. The sample was immediately sucked through the filter into the receiver tube kept at -5 to $-10^{\circ} \mathrm{C}$. The entire procedure was completed almost instantaneously. The fact that the residual concentration of methanol was found to be independent of the cell concentration in the chemostat indicates that there was negligible loss of methanol due to microbial consumption under these sampling conditions. Additionally, the range of methanol consumption under the described growth conditions can be estimated from the known maximum specific substrate consumption rates for methanol (Egli, 1980), viz, 0.18 mg methanol ${ }^{-1} \mathrm{~s}^{-1}$ for a culture containing a cell concentration of $2 \mathrm{~g}$ dry weight $1^{-1}$. This may be compared to actual methanol concentrations found (approx. $1 \cdot 2 \mathrm{mg} \mathrm{l}^{-1}$ ).

Glucose was assayed by the GOD-Perid ${ }^{R}$-test (Boehringer) modified as follows. The deproteinization step was omitted and $0.2 \mathrm{ml}$ of the filtrate from the bacterial filter was added directly to $4.8 \mathrm{ml}$ of solution 2 containing buffer, enzyme and chromogen. The absorbance was read at $418 \mathrm{~nm}$ against a set of glucose standards. Under these conditions, the absolute detection level of glucose was $2 \mathrm{mg} \mathrm{ml}^{-1}$, which gave a net absorbance value of 0.018 . 
Methanol was analysed using a Pye Unicam series 104 gas chromatograph equipped with a flame-ionization detector. A glass column (length $1.8 \mathrm{~m}$ ) packed with Porapak Q (50-80 mesh) was used, $\mathrm{N}_{2}\left(40 \mathrm{ml} \mathrm{min}^{-1}\right)$ was the carrier gas, the column temperature was $160^{\circ} \mathrm{C}$ and the attenuation was set at 20 . With a sample of $3 \mu \mathrm{l}$ the absolute detection limit was $0 \cdot 1 \mathrm{mg} \mathrm{l}^{-1}$. For residual methanol concentrations lower than $5 \mathrm{mg}^{-1}$ the deviations from the mean value were always less than $\pm 15 \%$ : with residual methanol concentrations higher than $5 \mathrm{mg} \mathrm{l}^{-1}$ the deviations from the mean values were less than $\pm 5 \%$.

\section{RESULTS}

\section{Regulation of the synthesis of assimilatory enzymes during glucose/methanol-limited growth}

Kloeckera sp. 2201 was grown carbon-limited in chemostat culture at a constant dilution rate of $0 \cdot 14 \mathrm{~h}^{-1}$ with glucose, methanol and glucose/methanol mixtures as carbon and energy source. The specific activities of eight enzymes involved in the assimilation of the two carbon sources were measured (Fig. 2). The specific activities of DHA synthase, DHA kinase, fructose-1,6bisphosphatase, ribose-5-phosphate isomerase and ribulose-5-phosphate 3-epimerase increased approximately linearly with increasing proportions of methanol in the supplied glucose/methanol mixture until the maximum specific activity was reached which corresponded to the levels of these enzymes found in methanol-grown cells. Further increase in the proportion of methanol did not result in further increase in specific activity. For DHA synthase, fructose-1,6bisphosphatase, ribose-5-phosphate isomerase and ribulose-5-phosphate 3-epimerase maximum induction was already reached with a mixture of $40 \%$ methanol $/ 60 \%$ glucose whereas $60 \%$ methanol was needed for maximum specific activity of DHA kinase (Fig. 2). In extracts from cells growing solely on glucose very low specific activities of the first three enzymes of the XuMP cycle, viz. DHA synthase, DHA kinase and fructose-1,6-bisphosphatase, could be detected $\left(0.005,0.015\right.$ and $0.005 \mu \mathrm{mol} \mathrm{mg}{ }^{-1} \mathrm{~min}^{-1}$ respectively). Taking the specific activities in methanol-grown cells as $100 \%$ the degree of derepression observed in glucose-grown cells was $6.3 \%$ (DHA synthase), $6.5 \%$ (DHA kinase) and $4.2 \%$ (fructose-1,6-bisphosphatase). Considerable activities of ribulose-5-phosphate epimerase and ribose-5-phosphate isomerase, namely 19.2 and $28.6 \%$ of these activities in methanol-grown cells, were measured in extracts from cells grown on glucose.

In contrast, the remaining three enzymes of the XuMP cycle, viz, fructose-1,6-bisphosphate aldolase, transaldolase and transketolase, showed different behaviour (Fig. 2). A nearly linear, threefold increase of the specific activity of fructose-bisphosphate aldolase from $0.7 \mu \mathrm{mol}$ $\mathrm{mg}^{-1} \mathrm{~min}^{-1}$ during growth on glucose to $1.9 \mu \mathrm{mol} \mathrm{mg}^{-1} \mathrm{~min}^{-1}$ during growth on methanol was observed. The levels of transaldolase were not affected by increase of the methanol proportion up to $50 \%$; with higher proportions of methanol, however, a slight increase from $0 \cdot 11$ to $0 \cdot 19 \mu \mathrm{mol} \mathrm{mg}^{-1} \mathrm{~min}^{-1}$ was found. The pattern for transketolase activity was different from those for all the other enzymes of the XuMP cycle. A slightly lower specific activity $\left(0.50 \mu \mathrm{mol} \mathrm{mg}^{-1} \mathrm{~min}^{-1}\right)$ for this enzyme was measured in methanol-grown cells compared to glucose-grown cells $\left(0.60 \mu \mathrm{mol} \mathrm{mg}^{-1} \mathrm{~min}^{-1}\right)$. It has to be mentioned that the measured transketolase activity is the sum of "classical' transketolase activity (transferring glycolaldehyde from xylulose 5-phosphate to ribose 5-phosphate) and DHA synthase activity (transferring glycolaldehyde from xylulose 5-phosphate to formaldehyde) since Waites \& Quayle (1981) reported that DHA synthase also exhibits 'classical' transketolase activity. According to these authors the classical transketolase activity of DHA synthase from Candida boidinii is approximately one to two times its DHA synthase activity. If this holds for the DHA synthase from Kloeckera sp. 2201 as well, a specific activity of 0.075 to $0.15 \mu \mathrm{mol} \mathrm{mg}^{-1} \mathrm{~min}^{-1}$ has to be deducted from the transketolase activity given in Fig. 2 for cells growing with methanol. After such a correction the specific activity of classical transketolase would be $(0.425-0.350) \mu \mathrm{mol}$ $\mathrm{mg}^{-1} \mathrm{~min}^{-1}$ for methanol-grown cells.

The specific activity patterns of glycolytic enzymes not directly involved in the generation of $\mathrm{C}_{3}$ units from methanol via the XuMP cycle are shown in Fig. 3. A close connection with glucose metabolism was observed for phosphofructokinase: the specific activity dropped when the proportion of glucose was lowered. However, no complete repression of the synthesis of phosphofructokinase occurred even though this enzyme has no obvious function during growth 


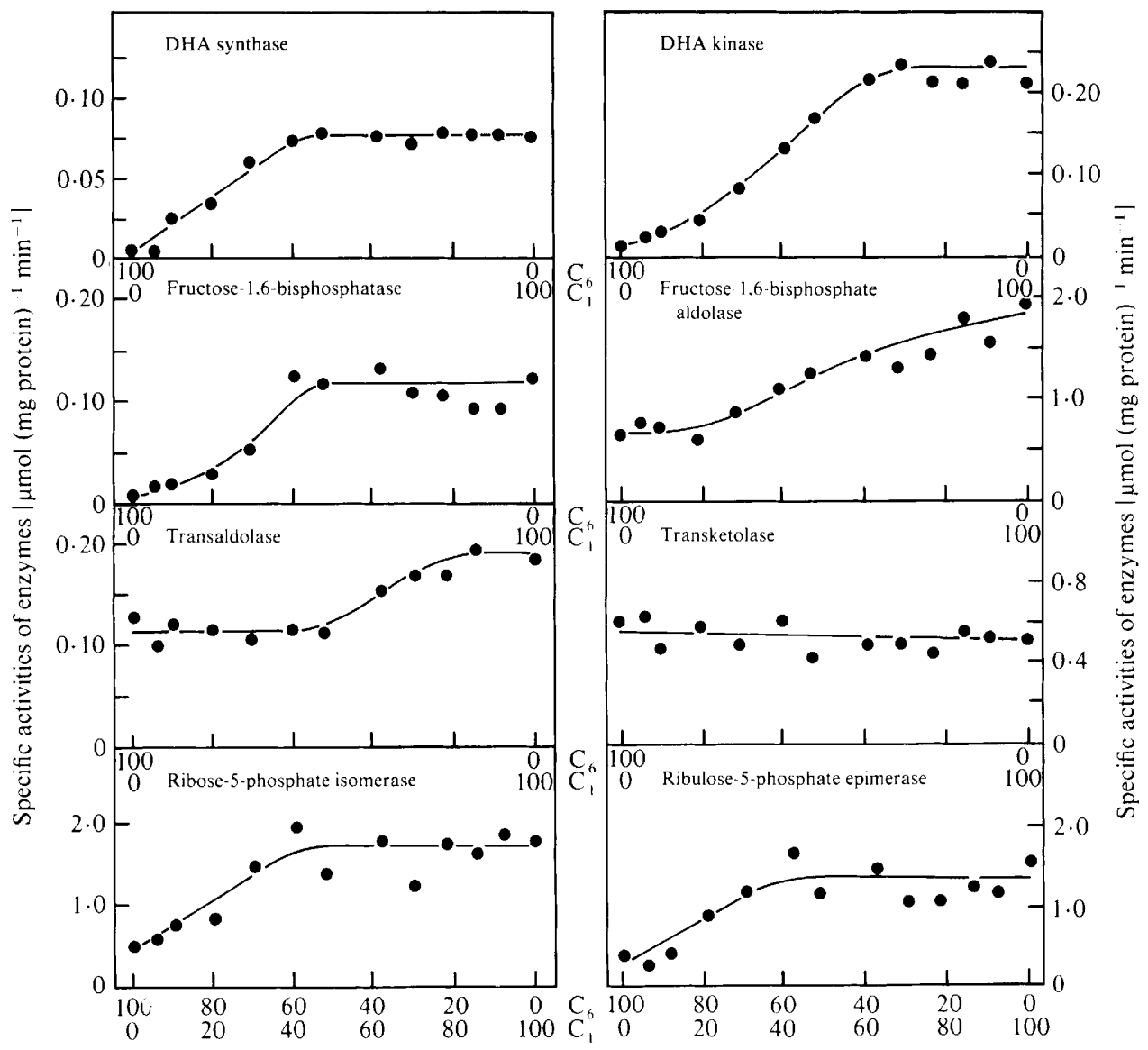

Proportions of glucose $\left(C_{6}\right)$ and methanol $\left(C_{1}\right)$ in inflowing medium $(\%, w / w)$

Fig. 2. Specific activities of enzymes in extracts of Kloeckera sp. 2201 grown carbon-limited in chemostat culture at a fixed dilution rate of $0 \cdot 14 \mathrm{~h}^{-1}$, as a function of the composition (given in $\%, w / w$ ) of the glucose methanol mixture supplied as carbon and energy sources in the inflowing medium.

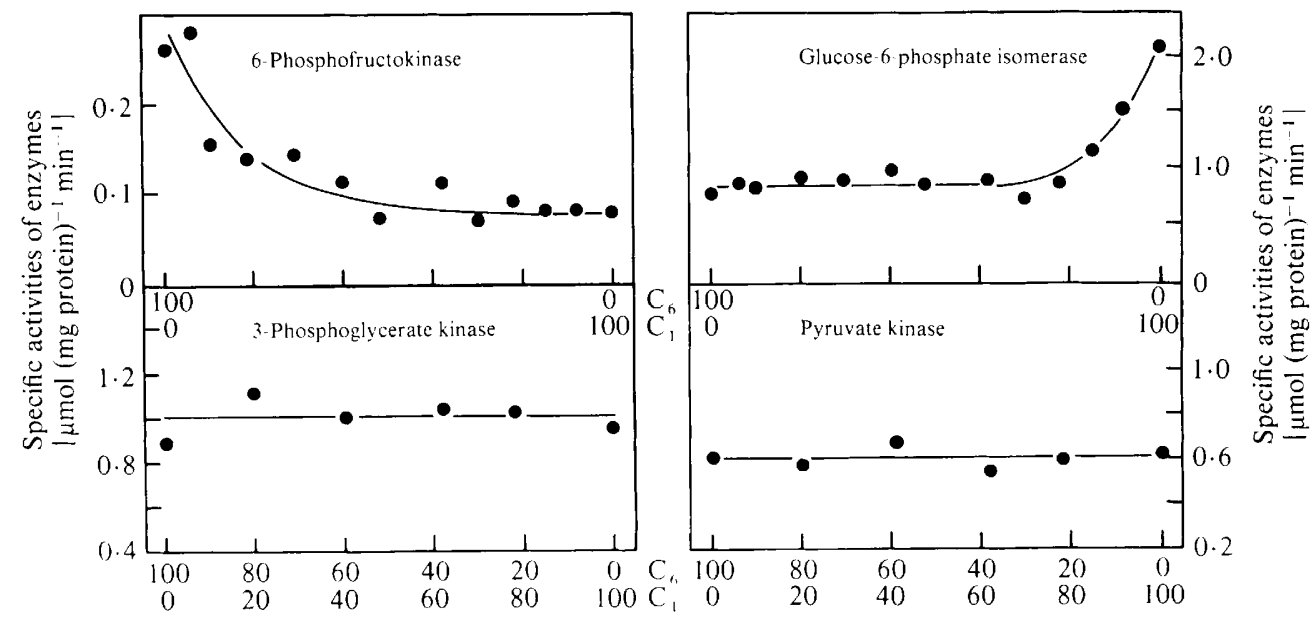

Proportions of glucose $\left(\mathrm{C}_{\mathrm{f}}\right)$ and methanol $\left(\mathrm{C}_{1}\right)$ in inflowing medium $(\%, w / w)$

Fig. 3. Specific activities of enzymes in extracts of Kloeckera sp. 2201 grown carbon-limited in chemostat culture at a fixed dilution rate of $0 \cdot 14 \mathrm{~h}^{-1}$, as a function of the composition (given in $\%$, w/w) of the glucose methanol mixture supplied as carbon and energy sources in the inflowing medium 


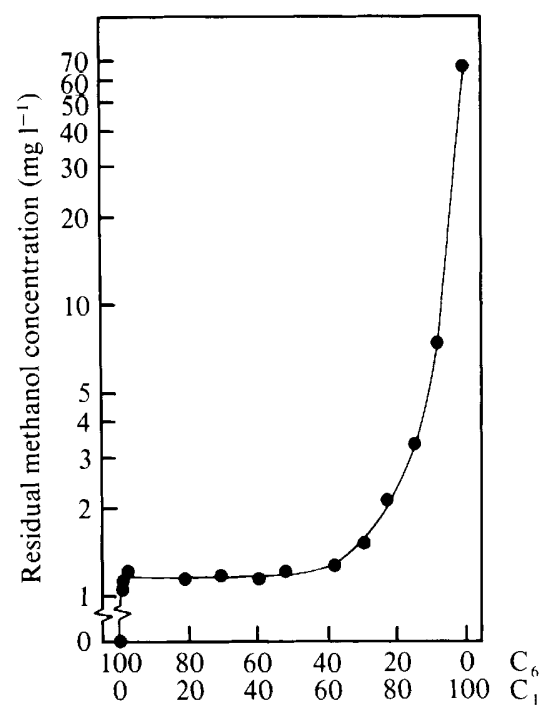

Proportions of glucose $\left(\mathrm{C}_{6}\right)$ and methanol $\left(\mathrm{C}_{1}\right)$ in inflowing medium $(\%, w / w)$

Fig. 4. Concentration of residual methanol in a culture of Kloeckera sp. 2201 growing carbon-limited in a chemostat at a constant dilution rate of $0 \cdot 14 \mathrm{~h}^{-1}$ as a function of the composition (given in $\%$, w/w) of the glucose/methanol mixture supplied as carbon and energy sources in the inflowing medium.

on methanol. Growth on mixtures containing more than $80 \%$ methanol was accompanied by a twofold increase in the specific activity of glucose-6-phosphate isomerase. No influence of the changing substrate mixture on the specific activities of 3-phosphoglycerate kinase and pyruvate kinase was detected.

\section{Residual substrate concentrations during glucose/methanol-limited growth}

During glucose/methanol-limited growth of Kloeckera sp. 2201 in a chemostat at a constant dilution rate of $0 \cdot 14 \mathrm{~h}^{-1}$ the culture filtrate was analysed for the residual concentrations of the two carbon sources. Residual methanol in the culture filtrate could be measured reproducibly and its concentration is plotted in Fig. 4 as a function of the composition of the glucose/methanol mixture in the inflowing medium. No methanol was detected when glucose was the only carbon source. However, with proportions of methanol as little as $1.4 \%$ its residual concentration was found to be in the range of $1 \cdot 0-1 \cdot 2 \mathrm{mg} \mathrm{l}^{-1}$. No significant influence of the total substrate concentration in the inflowing medium on the residual methanol concentration could be observed, e.g. for the two mixtures $0.055 \mathrm{~g} \mathrm{C}_{1} \mathrm{1}^{-1 / 3} \cdot 97 \mathrm{~g} \mathrm{C}_{6} \mathrm{l}^{-1}$ and $0.032 \mathrm{~g} \mathrm{C}_{1} \mathrm{l}^{-1} / 2.22 \mathrm{~g} \mathrm{C}_{6} \mathrm{l}^{-1}$ (composition for both mixtures $1.4 \% \mathrm{C}_{1} / 98 \cdot 6 \% \mathrm{C}_{6}$ ) the measured mean values of the residual methanol concentrations were 1.03 and $1.12 \mathrm{mg} \mathrm{l}^{-1}$. The residual concentration of methanol was found to be considerably lower during growth with glucose/methanol mixtures compared to growth with methanol alone. With proportions of methanol lower than $50 \%$ the residual concentration remained constant at about $1.2 \mathrm{mg} \mathrm{l}^{-1}$. When the cells were growing on a mixture which contained more than $50 \%$ methanol a dramatic increase in the methanol concentration in the culture filtrate was observed. Finally, during growth on methanol alone a residual concentration of $67 \mathrm{mg} \mathrm{l}^{-1}$ was measured in the culture filtrate. That the data presented in Fig. 4 are not due to incomplete mixing of the culture liquid was tested by withdrawing the sample from the top (near the medium inflow) and the bottom of the culture vessel. No significant concentration differences could be detected between these two sampling places.

The concentration of glucose in the culture filtrate was found to be below the detection limit (about $2 \mathrm{mg} \mathrm{l}^{-1}$ ) of the method used. Several attempts were made to stop cellular metabolism immediately by sampling the culture liquid directly into trichloroacetic or perchloric acid. However, no reproducible data for residual glucose could be obtained. 
DISCUSSION

\section{Regulation of enzyme synthesis}

The data presented in this paper confirm that methanol is assimilated in Kloeckera sp. 2201 via the XuMP cycle of formaldehyde fixation. The induction patterns of the two key assimilatory enzymes of the XuMP cycle, viz. DHA synthase and DHA kinase, as a function of the supplied $C_{1} / C_{6}$ mixture, were similar to those found in the same yeast for the four dissimilatory enzymes alcohol oxidase, catalase and the two dehydrogenases for formaldehyde and formate (Egli et al., 1982a). This indicated that the synthesis of these assimilatory and dissimilatory enzymes might be regulated by a similar mechanism at the molecular level. However, under the experimental conditions described, typical 'methanol induction patterns' were not restricted to enzymes known to be involved solely in methanol metabolism. The same kind of pattern was also found for fructose-1,6-bisphosphatase, ribulose-5-phosphate epimerase and ribose-5-phosphate isomerase. The induction of the last two enzymes clearly reflects their importance in the rearrangement reactions of the XuMP cycle. The induction of all the key enzymes of the XuMP cycle under glucose/methanol-limited growth conditions confirms the reported assimilation of carbon from ${ }^{14} \mathrm{C}$-labelled methanol under similar growth conditions (Egli et al., 1982a). With respect to fructose-1,6-bisphosphatase it is worth mentioning that in some facultative autotrophs the enzyme functioning in the Calvin cycle is different from the enzyme involved in gluconeogenesis (Amachi \& Bowien, 1979). In the methylotrophic yeast Hansenula polymorpha, however, there is no evidence for multiplicity of fructose-1,6bisphosphatases purified from ethanol and methanol-grown cells (Attwood \& van Dijken, 1982). These authors found that this enzyme had no activity with sedoheptulose 1,7-bisphosphate and therefore does not take part in the rearrangement reactions of the XuMP cycle from fructose 6phosphate to xylulose 5-phosphate. Furthermore they detected no sedoheptulose-1,7bisphosphatase activity in extracts of methanol-grown $H$. polymorpha. Because of the strong similarities between $H$. polymorpha and the organism used in this study (Egli et al., 1980; Egli et $a l ., 1982 a, b)$ it is likely that in Kloeckera sp. 2201 also, fructose-1,6-bisphosphatase is involved only in the dephosphorylation of fructose-1,6-bisphosphate. A different pattern of regulation of the remaining three enzymes of the assimilatory cycle showed little (fructose-bisphosphate aldolase and transaldolase) or no relation (transketolase) to the proportion of methanol in the inflowing medium.

In order to assess the role of the enzymes involved in the rearrangement reactions during growth with either glucose or methanol and hence to rationalize the different specific activity patterns found in Fig. 2, the flux of substrate through the individual enzyme reactions was calculated (Table 1). In the case of glucose it was assumed that either $20 \%$ (a value reported for Candida utilis; Schlegel, 1981) or $60 \%$ (an extremely high proportion, reported for Candida 107 ; Ratledge \& Botham, 1977) of the substrate was degraded via the oxidative pentose phosphate cycle to give fructose 6-phosphate and glyceraldehyde 3-phosphate. Assimilation of carbon was assumed to take place at the level of glyceraldehyde 3-phosphate. Table 1 shows that the expected substrate fluxes through the enzymes of the pentose phosphate cycle, i.e. transketolase, transaldolase, ribulose-5-phosphate epimerase and ribose-5-phosphate isomerase, should be 10to 20-fold higher during growth on methanol as compared to growth on glucose (assuming that $20 \%$ of the latter is metabolized via the pentose phosphate cycle). Even if it is assumed that $60 \%$ of the supplied glucose is degraded via these enzymes the flux increase during growth on methanol should still be 3- to 6-fold higher as compared to growth on glucose. The actual increases in specific activities of ribulose-5-phosphate epimerase (3.5-fold) and ribose-5phosphate isomerase $(5 \cdot 2$-fold) are thus fully consistent with $60 \%$ of the glucose being degraded by oxidative pentose phosphate cycle. The $2 \cdot 8$-fold increase in specific activity of fructose-1,6bisphosphate aldolase corresponds well with the calculated flux increase for either $20 \%$ or $60 \%$ of the glucose being metabolized via EMP glycolysis. The calculated 7- to 20-fold increases in substrate flux for transketolase and transaldolase, however, are not reflected in the ratios of the actual specific activities measured for these enzymes.

The potential substrate flux that could theoretically be carried by each of the individual enzymes can be calculated from their measured specific activities (assuming that the enzymes 
Table 1. Substrate fluxes for enzymes involved in carbon assimilation during growth of Kloeckera sp. 2201 on methanol or glucose as carbon and energy source

The organism was grown at a dilution rate of $0 \cdot 14 \mathrm{~h}^{-1}$ with either methanol $\left(\mathrm{C}_{1}\right)$ or glucose $\left(\mathrm{C}_{6}\right)$ as carbon and energy source. It is assumed that either $20 \%$ or $60 \%$ of the glucose is metabolized via the oxidative pentose phosphate pathway to give fructose 6-phosphate and glyceraldehyde 3-phosphate, the remainder being metabolized by EMP glycolysis. For the calculation of the expected $q_{\mathrm{s}}$ see Appendix. The ratio of the specific activities of each enzyme was calculated from the experimentally determined values shown in Fig. 2. The potential $q_{\mathrm{s}}$ was calculated from the measured specific enzyme activities assuming the protein content of the cells to be $50 \%$. DHA, dihydroxyacetone; $\mathrm{F} 1,6 \mathrm{P}$ fructose 1,6-bisphosphate; Ri5P, ribose 5-phosphate; Ru5P, ribulose 5-phosphate; Sp. a., enzyme specific activity.

\begin{tabular}{|c|c|c|c|c|c|c|c|c|c|}
\hline \multirow[b]{3}{*}{ Enzyme } & \multicolumn{5}{|c|}{$\begin{array}{c}q_{\mathrm{s}} \text { expected } \\
{\left[\mu \mathrm{mol}(\mathrm{mg} \text { dry biomass })^{-1} \mathrm{~h}^{-1}\right]}\end{array}$} & \multirow{3}{*}{$\begin{array}{l}\text { Sp. a. } C_{1} / \\
\text { Sp. a. } C_{6}\end{array}$} & \multirow{2}{*}{\multicolumn{3}{|c|}{$q_{\mathrm{s}}$ potential $/ q_{\mathrm{s}}$ expected }} \\
\hline & & \multicolumn{2}{|c|}{$\mathrm{C}_{6}$} & \multicolumn{2}{|c|}{$\mathrm{C}_{1} / \mathrm{C}_{6}$} & & & & \\
\hline & $\mathrm{C}_{1}$ & $20 \%$ & $60 \%$ & $20 \%$ & $60 \%$ & & $\mathrm{C}_{1}$ & $\mathrm{C}_{6}(20 \%)$ & $C_{6}(60 \%)$ \\
\hline F1,6P aldolase & $3 \cdot 88$ & $1 \cdot 32$ & $1 \cdot 132$ & $2 \cdot 94$ & $3 \cdot 43$ & $2 \cdot 8$ & $14 \cdot 7$ & $15 \cdot 5$ & $18 \cdot 0$ \\
\hline Transketolase & $3 \cdot 88$ & $0 \cdot 188$ & $0 \cdot 566$ & $20 \cdot 6$ & $6 \cdot 86$ & $0 \cdot 83$ & 3.9 & $95 \cdot 7$ & $31 \cdot 8$ \\
\hline Transaldolase & 1.94 & $0 \cdot 094$ & $0 \cdot 282$ & $20 \cdot 6$ & $6 \cdot 86$ & $1 \cdot 73$ & 2.9 & $35 \cdot 1$ & $11 \cdot 7$ \\
\hline Ru5P epimerase & 1.94 & $0 \cdot 188$ & 0.566 & $10 \cdot 3$ & $3 \cdot 43$ & $5 \cdot 20$ & $21 \cdot 6$ & $43 \cdot 1$ & $14 \cdot 3$ \\
\hline $\mathrm{Ri} 5 \mathrm{P}$ isomerase & 1.94 & $0 \cdot 094$ & $0 \cdot 282$ & $20 \cdot 6$ & $6 \cdot 86$ & $3 \cdot 50$ & $27 \cdot 1$ & $159 \cdot 6$ & $53 \cdot 2$ \\
\hline DHA synthase & $5 \cdot 82$ & 0 & 0 & 0 & 0 & $16 \cdot 0$ & $0 \cdot 41$ & -- & - \\
\hline DHA kinase & 2.91 & 0 & 0 & 0 & 0 & $15 \cdot 3$ & $2 \cdot 4$ & $\ldots$ & - \\
\hline F1,6Pase & $3 \cdot 88$ & 0 & 0 & 0 & 0 & $24 \cdot 0$ & 0.9 & - & - \\
\hline Methanol oxidase & $11 \cdot 5$ & 0 & 0 & 0 & 0 & $30 \cdot 0^{*}$ & $3 \cdot 9^{*}$ & - & $\cdots-$ \\
\hline $\begin{array}{l}\text { Formaldehyde } \\
\text { dehydrogenase }\end{array}$ & $5 \cdot 69$ & 0 & 0 & 0 & 0 & $5 \cdot 0^{*}$ & $7 \cdot 9^{*}$ & - & - \\
\hline $\begin{array}{l}\text { Formate } \\
\text { dehydrogenase }\end{array}$ & $5 \cdot 69$ & 0 & 0 & 0 & 0 & $160^{*}$ & $1 \cdot 7^{*}$ & - & -- \\
\hline
\end{tabular}

are considered to operate in vivo under conditions of substrate saturation) and these were compared with the expected substrate flux. From this ratio a value for the 'excess activity' of an enzyme can be roughly estimated ( $q_{\mathrm{s}}$ potential $/ q_{\mathrm{s}}$ expected). The results in Table 1 show that theoretically the enzymes of the pentose phosphate pathway are present in high excess during growth on glucose. During growth on methanol, however, this overcapacity is drastically reduced in the case of transketolase and transaldolase. This leads to the possibility that they might be rate-limiting in the assimilation of methanol. Another plausible explanation for such a discrepancy between glucose- and methanol-limited growth would be a change in intracellular substrate concentrations which would increase the actual flux through transketolase and transaldolase in cells growing on methanol. Isolation of a mutant with enhanced transketolase and transaldolase activities might give an answer to this question.

The three enzymes DHA synthase, DHA kinase and fructose-1,6-bisphosphatase are presumed to have no role during metabolism of glucose and hence, in their case, calculation of potential and expected substrate fluxes can only be performed for growth on methanol. The results of these calculations are given in Table 1 . In all three cases the ratios $q_{\mathrm{s}}$ potential $/ q_{\mathrm{s}}$ expected indicate that they might be candidates for rate-limitation during growth on methanol. However, it must be borne in mind that DHA synthase is both difficult to assay and is extremely unstable in crude extracts (Waites \& Quayle, 1981). Fructose-1,6-bisphosphatase is also another enzyme whose activity in crude extracts is very sensitive to changes in $\mathrm{pH}$, presence of chelating agents, metal ion concentration, etc. (Attwood \& van Dijken, 1982). These activities may therefore be underestimated.

Data of Egli et al. (1982a) have also been included for comparative purposes in Table 1 on the activities of the enzymes involved in the direct catabolism of methanol, viz. methanol oxidase, formaldehyde dehydrogenase and formate dehydrogenase. Once again, the low value for $q_{\mathrm{s}}$ 
potential $/ q_{\mathrm{s}}$ expected for formate dehydrogenase should be treated with caution because the enzyme was assayed (Egli et al., 1982a) with formate as substrate instead of the physiological substrate, formyl-glutathione. These data make it unlikely that direct catabolism of methanol is rate-limiting during growth on methanol.

Egli et al. $(1982 a, b)$ raised the possibility that methanol might be oxidized by a cyclic pathway involving glucose-6-phosphate dehydrogenase, 6-phosphogluconate dehydrogenase and reactions of the XuMP pathway. On the basis of the relative changes in activities of catabolic enzymes during mixed substrate growth these authors concluded that such a cyclic pathway played no major role in dissimilation of methanol, the glucose-6-phosphate dehydrogenase and 6-phosphogluconate dehydrogenase being involved mainly in glucose metabolism. Our present studies confirm this view. The XuMP cycle has to turn three times to synthesize one molecule of triose phosphate and hence six times for synthesis of one molecule of hexose phosphate. Since the specific activities of several enzymes of the XuMP cycle are apparently close to being ratelimiting with respect to assimilation it seems unlikely that they would support an appreciable carbon flux at a rate six times that of the resulting indirect catabolism of formaldehyde to carbon dioxide. This would seem particularly unlikely when the activities of the direct formaldehydeand formate dehydrogenases are not rate-limiting with respect to dissimilation.

It should be emphasized that the present studies have been performed at a constant dilution rate, in contrast to related studies where the dilution rate has been changed while the substrate mixture has been constant (Eggeling \& Sahm 1981; Egli et al., 1982b). Both these groups of investigators have shown that methanol can be fully utilized in a mixed substrate at dilution rates considerably in excess of the $\mu_{\max }$ for methanol alone. Eggeling \& Sahm (1981) therefore raise the question as to what limits the growth rate on methanol alone and they speculate that an assimilatory enzyme is likely to be a candidate. Our present studies indicate that transketolase, transaldolase, DHA synthase, DHA kinase and fructose-1,6-bisphosphatase should be viewed as possible candidates for pacemaker enzymes.

Phosphofructokinase showed the same regulation pattern as was previously found for hexokinase, glucose-6-phosphate dehydrogenase and 6-phosphogluconate dehydrogenase by Egli et al. (1982a) and the close relationship of these enzyme patterns to the specific glucose consumption rate was pointed out by these authors. The exceptional behaviour of glucose-6phosphate isomerase might be due to a shortage of intracellular glucose 6-phosphate as the ratio of methanol to glucose was increased in the feed: whereas during growth on glucose, sufficient glucose 6-phosphate may be available for the synthesis of polysaccharides and the generation of NADPH via glucose-6-phosphate- and 6-phosphogluconate dehydrogenases, during growth on glucose/methanol the organism might be forced to enhance the supply of glucose 6-phosphate from fructose 6-phosphate. Although the specific activities of all glycolytic enzymes leading from glucose to glyceraldehyde 3-phosphate were found to be affected, those of 3phosphoglycerate kinase and pyruvate kinase were not dependent on the composition of the mixed growth substrate. This is somewhat surprising because, during growth on glucose, carbon for both assimilation and dissimilation has to be metabolized by these enzymes whereas during growth with methanol only the carbon for biosynthetic purposes.

\section{Residual concentrations of methanol}

When in steady-state, single substrate-limited growth at a constant dilution rate is characterized by a constant specific rate of consumption, $q_{\mathrm{s}}$, of this substrate. Assuming that growth can be described in terms of Monod kinetics, $q_{\mathrm{s}}$ is given by:

$$
q_{\mathrm{s}}=q_{\mathrm{m}} \cdot s /\left(K_{\mathrm{s}}+s\right)
$$

The introduction of a second limiting substrate changes the situation in such a way that $q_{\mathrm{s}}$ becomes a function of the composition of the supplied substrate mixture in the inflowing medium, even though the dilution rate is constant. It has to be added here that this second substrate must be biomass-generating, either directly by incorporation into biomass or indirectly 
via production of energy from which more of the first substrate can be assimilated. A separate consumption rate can then be calculated for each of two limiting substrates 1 and 2:

$$
\begin{aligned}
& q_{\mathrm{s}_{1}}=D\left(s_{0_{1}}-s_{1}\right) / x \\
& q_{\mathrm{s}_{2}}=D\left(s_{0_{2}}-s_{2}\right) / x
\end{aligned}
$$

Such changes in $q_{\mathrm{s}}$ have been reported (Egli et al., 1982a) for a similar experiment to that described in this paper.

For single substrate-limited growth it is generally accepted that $q_{\mathrm{s}}$ is a function of the extracellular substrate concentration, such as described in equation 1 (compare Powell, 1967). Under these conditions it is assumed that $q_{\mathrm{m}}$ and $K_{\mathrm{s}}$ are constant. Applying this concept to glucose/methanol-limited growth with respect to methanol - as it is described in this paper - it may be seen that the changes in $q_{\mathrm{C}_{1}}$ as a function of the mixture composition imply changes in the residual methanol concentration. However, during growth with mixtures up to $50 \%$ methanol where the residual concentration of this substrate is approximately constant, our experimental data in Fig. 4 contradict this theory and it follows from equation 1 that either $q_{\mathrm{m}}$ or $K_{\mathrm{s}}$ for methanol, or both, should have changed. Similar observations were made by Law \& Button (1977). These authors found for a marine bacterium that the residual concentration of glucose was lower during glucose/arginine-limited growth than during growth with glucose as the only carbon source. They showed that $K_{\mathrm{s}}$ for glucose was lowered by the addition of the second carbon source. At the present time it cannot be decided which of the two parameters $q_{\mathrm{m}}$ and $K_{\mathrm{s}}$ are influenced by mixed-substrate growth and what the mechanism of this effect at the molecular level might be. Further data are needed to show if the familiar model developed by Monod is also valid for growth on substrate mixtures or if the kinetics of mixed-substrate growth must be solved in another way (e.g. see Law et al., 1976).

The data reveal a striking relation between methanol concentration and enzyme specific activity. As long as the residual methanol concentration was constant, i.e. when the proportion of methanol in the inflowing medium was between 0 and $50 \%$, the specific activities of the key enzymes of the XuMP cycle increased. By contrast, when the enzyme specific activities were constant, i.e. with methanol proportions higher than $50 \%$, the residual concentration of methanol increased with increasing proportion of methanol in the supplied mixture. From this it seems that the cells growing under dual substrate limitation operated two mechanisms for adjusting their specific rate of methanol consumption: (a) by changing the cellular enzyme composition, or (b) by taking advantage of increasing concentration of the substrate per se and thereby effecting a higher $q_{\mathrm{s}}$ at a constant enzyme capacity. The latter of these two possibilities is a more 'passive' solution to the problem than is the former. It remains to be seen whether this kind of regulation is limited to just methanol or whether it operates for other substrates as well. However, it is interesting to note that a similar induction pattern to that for the methanoldissimilating enzymes was found for citrate permease in Pseudomonas aeruginosa growing nitrogen-limited at a constant dilution rate with mixtures of glucose and citrate $(\mathrm{Ng} \&$ Dawes, 1973).

The results presented in this paper show that the residual concentration of methanol in a culture of Kloeckera sp. 2201 growing at a constant dilution rate was considerably lower during mixed-substrate growth with methanol plus glucose than when methanol was the only limiting carbon source. If more sensitive assays for the residual concentration of the second limiting substrate, glucose, should show a similar pattern during the converse experiment of going from methanol to glucose limitation, then it would demonstrate a complete case in which mixedsubstrate growth resulted in a crucial advantage for an organism in such an environment since the compensatory splitting of the 'overall $q_{\mathrm{s}}$ ' into different consumption rates for the various substrates would allow a relatively fast growth rate at very low substrate concentrations. Such a strategy could enable an organism capable of this tuning of its utilization of mixed substrates, to compete with specialists which can utilize just one of the limiting substrates present but with a higher affinity. Indeed, successful competition of a metabolically versatile, facultative thiobacillus with a specialized obligately autotrophic thiobacillus under mixed substrate 
conditions was predicted by Rittenberg (1972) and has now been experimentally confirmed by Gottschal et al. (1979). It will be of interest to examine whether this strategy is found to operate over a wider range of mixed substrates and organisms.

\section{APPENDIX}

\section{Calculation of substrate fluxes}

The established metabolic routes for glucose and methanol allow the substrate flux for individual enzymes involved in these pathways to be calculated from the specific substrate consumption rates, $q_{\mathrm{s}}$, and the distribution of carbon between assimilatory and dissimilatory sequences. The specific substrate consumption rate is given by the equation $q_{\mathrm{s}}=\mu .\left(Y_{\mathrm{x} / \mathrm{s}}\right)^{-1}$, where $\mu$ is the specific growth rate $\left(\mathrm{h}^{-1}\right)$ and $Y_{\mathrm{x} / \mathrm{s}}$ the growth yield [g dry biomass (g substrate) $)^{-1}$ ]. The proportions of assimilated $\left(Y_{\mathrm{C} / \mathrm{s}}\right)$ and dissimilated $\left(1-Y_{\mathrm{C} / \mathrm{s}}\right)$ carbon can be calculated from the growth yield and the carbon content of the formed dry biomass $\left(C_{\mathrm{b}}\right)$ and the supplied substrate $\left(C_{\mathrm{s}}\right)$, thus $Y_{\mathrm{C} / \mathrm{s}}=Y_{\mathrm{x} / \mathrm{s}} \cdot C_{\mathrm{b}} \cdot C_{\mathrm{s}}^{-1}$, where $Y_{\mathrm{C} / \mathrm{s}}$ is $\mathrm{g}$ cell carbon ( $\mathrm{g}$ substrate carbon utilized $)^{-1}$.

For Kloeckera sp. 2201 the growth yields for glucose $\left(Y_{\mathrm{x} / \mathrm{C}_{6}}\right)$ and methanol $\left(Y_{\mathrm{x} / \mathrm{C}_{1}}\right)$ were reported to be 0.55 and 0.38 , respectively (Egli et al., 1982a), and the average carbon content of the cells was assumed to be $50 \%$ (compare Harder \& van Dijken, 1975). With these figures and the dilution rate used in the experiment reported in this paper $\left(0 \cdot 14 \mathrm{~h}^{-1}\right)$ the following values were obtained: $q_{\mathrm{C}_{1}}=11.51 \mu \mathrm{mol}$ methanol (mg dry biomass) $)^{-1} \mathrm{~h}^{-1} ; q_{\mathrm{C}_{6}}=1.414 \mu \mathrm{mol}$ glucose (mg dry biomass) $)^{-1} \mathrm{~h}^{-1} ; Y_{{\mathrm{C} / \mathrm{C}_{1}}_{1}}=0.51 \mathrm{~g}$ cell carbon (g methanol carbon utilized) $)^{-1} ; Y_{\mathrm{C}_{\mathrm{C}}}=0.69 \mathrm{~g}$ cell carbon (g glucose carbon utilized) $)^{-1}$.

The substrate fluxes during growth of Kloeckera sp. 2201 at a dilution rate of $0 \cdot 14 \mathrm{~h}^{-1}$ on methanol and glucose are shown in Figs A1 and A2. It is assumed that either $20 \%$ or $60 \%$ of the glucose is metabolized via the pentose phosphate cycle to give fructose 6-phosphate and glyceraldehyde 3 -phosphate whereas the remainder is degraded via the glycolytic pathway.
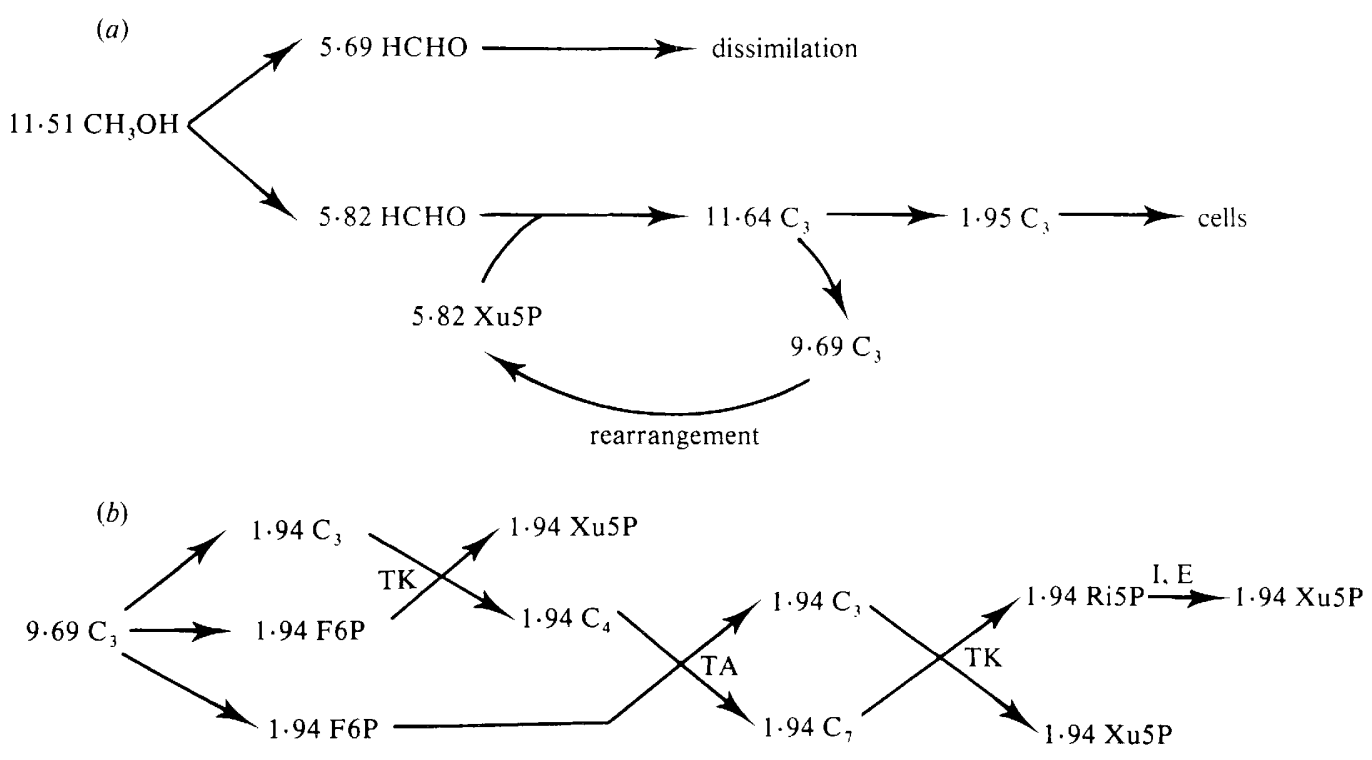

Fig. Al. Substrate fluxes [ $\mu$ mol substrate (mg dry biomass) $)^{-1} \mathrm{~h}^{-1}$ ] during growth of Kloeckera sp. 2201 on methanol at a dilution rate of $0 \cdot 14 \mathrm{~h}^{-1}$ using the XuMP pathway. (a) Overall metabolism; (b) expansion of rearrangement reactions from $(a)$. E, ribulose 5-phosphate epimerase; F6P, fructose 6phosphate; I, ribose-5-phosphate isomerase; TA, transaldolase; TK, transketolase; Xu5P, xylulose 5phosphate. 
(a)
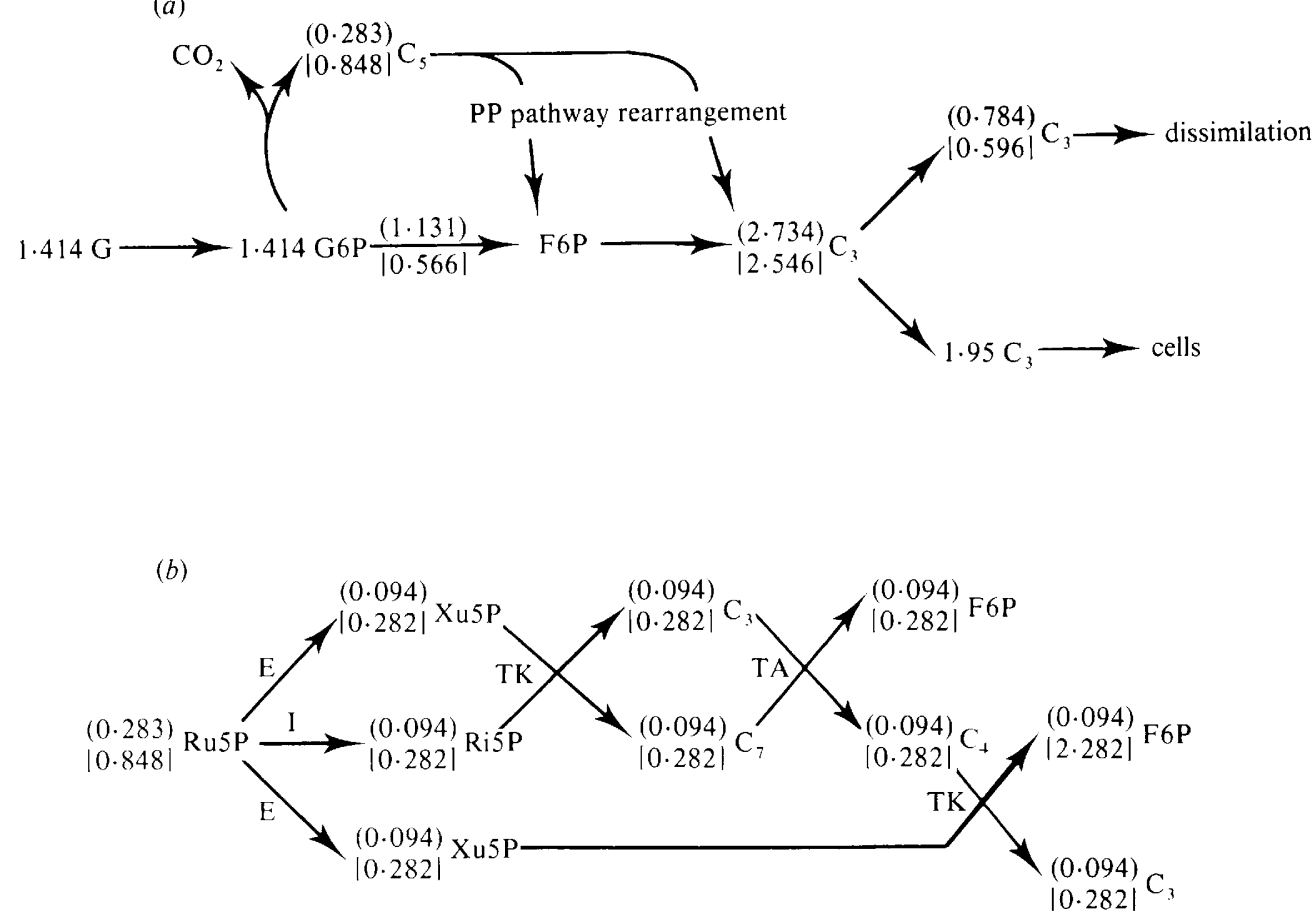

Fig. A2. Substrate fluxes [ $\mu$ mol substrate (mg dry biomass) ${ }^{-1} \mathrm{~h}^{-1}$ ] during growth of Kloeckera sp. 2201 on glucose at a dilution rate of $0 \cdot 14 \mathrm{~h}^{-1}$. It is assumed that either $20 \%$ (figures in round brackets) or $60 \%$ (figures in square brackets) of the glucose is metabolized via the pentose phosphate pathway. (a) Overall metabolism: (b) expansion of pentose phosphate cycle rearrangement from $(a)$. E, ribulose-5-phosphate epimerase: F6P, fructose 6-phosphate; G, glucose; G6P, glucose 6-phosphate; I, ribose-5-phosphate isomerase: Ri5P, ribose 5-phosphate: Ru5P, ribulose 5-phosphate: TA, transaldolase: TK, transketolase; Xu5P, xylulose 5-phosphate.

This work was financed by a Senior Visiting Fellowship (T.E.) and a research grant GR/A65966 (J. R. Q.) from the Science and Engineering Research Council. We thank Professor W. Harder for valuable discussions.

\section{REFERENCES}

Amachi, T. \& Bowien, B. (1979). Characterisation of two fructose bisphosphatase isoenzymes from the hydrogen bacterium Nocardia opaca l b. Journal of General Microbiology 113, 347-356

ATtwood, M. M. \& VAN DIJKEN, J. P. (1982). Characteristics of fructose-1,6-bisphosphatase from the methanol-utilizing yeast Hansenula polymorpha. Journal of General Microbiology 128, 2313-2317.

Babel, W. \& LoffHaGen, N. (1979). Assimilation of methanol by yeasts, a new approach. Zeitschrift für allgemeine Mikrobiologie 19, 299-302.

BAILEY, Y. E. \& Ollis, D. F. (1977). Biochemical Engineering Fundamentals, p. 349. New York: McGraw-Hill.

Bürcher, T. \& Pfleiderer, G. (1955). Pyruvate kinase from muscle. Methods in Enzymology 1, 435-440.

Bull, A. T. \& Brown, C. M. (1979). Continuous culture applications to microbial biochemistry. In Microhial Biochemistry. International Retiew of Biochemistry, vol. 21, pp. 177-226. Fdited by J. R Quayle. Baltimore: University Park Press. van Dijken, J. P. \& Qliayle, J. R. (1977). Fructose metabolism in four Pseudomonas species. Archives of Microbiology 114, 281-286.

van Dijken, J. P., Harder, W., Beardsmore, A. J. \& QUAYLE, J. R. (1978). Dihydroxyacetone: an intermediate in the assimilation of methanol by yeasts? FEMS Microbiology Letters 4, 97-102.

Fggeling, L. \& SAHM, H. (1980). Regulation of alcohol oxidase synthesis in Hansenula polymorpha: oversynthesis during growth on mixed substrates and induction by methanol. Archives of Microbiology 127, $119-124$.

FGgeling, L. \& SAHM, H. (1981). Enhanced utilization of methanol during growth on a mixed substrate: a continuous culture study with Hansenula polymorpha. Archices of Microbiology 130, 362365.

EGLI, T. (1980). Wachstum con Methanol-assimilierenden Hefen. Eine Chemostat-Studie üher die Regulation der Methanol-dissimilierenden Enzyme. Dissertation no. 6538, ETH, Zürich, Switzerland.

F.gLI, T. \& FIECHTER, A. (1981). Theoretical analysis of 
media used in the growth of yeasts on methanol. Journal of General Microbiology 123, 365-369.

EGLI, T. \& KäPPELI, O. (1980). Simultaneous utilisation of glucose and methanol in chemostat cultures of Hansenula polymorpha and Kloeckera sp. 2201. 3rd International Symposium on Microbial Growth on $C_{1}$. Compounds, Sheffield, U.K. (Abstract p. 19).

Egli, T., VAN DiJken, J. P., VeEnhuis, M., HaRder, W. \& FiECHTER, A. (1980). Methanol metabolism in yeasts: regulation of the synthesis of catabolic enzymes. Archices of Microbiology 124, 115-121.

Egli, T.. Käppeli, O. \& Fiechter, A. (1982a). Regulatory flexibility of methylotrophic yeasts in chemostat cultures: simultaneous assimilation of glucose and methanol at a fixed dilution rate. Archites of Microbiology 131, 1-7.

Egli. T., K ÄPPELI, O. \& Fiechter, A. (1982b). Mixed substrate growth of methylotrophic yeasts in chemostat culture: influence of the dilution rate on the utilisation of a mixture of glucose and methanol. Archices of Microbiology 131, 8-13.

Gottschal, J. C., DE Vries, S. \& Kuenen, J. G. (1979). Competition between the facultative chemolithotrophic Thiobacillus A2, an obligately chemolithotrophic Thiobacillus and a heterotrophic Spirillum for inorganic and organic substrates. Archives of Microbiology 121, 241-248.

Harder, W. \& DiJkhuizen, L. (1976). Mixed substrate utilization in microorganisms. In Continuous Culture 6: Applications and Ne'w Fields, pp. 297-314. Edited by A. C. R. Dean, D. C. Ellwood, C. G. T Evans \& T. Melling. Chichester \& Oxford: Ellis Horwood.

HARDER, W. \& DiJkhuizen, L. (1982). Strategies of mixed substrate utilization in microorganisms. In New Dimensions in Microbiology: Mixed Substrates, Mixed Cultures and Microbial Communities, pp. 459 480. Edited by J. R. Quayle \& A. T. Bull. London: Royal Society.

Hakder, W. \& VAN Dijken, J. P. (1975). A theoretical study of growth yields of yeasts on methanol. In Microbial Growth on $C_{1}$-Compounds, pp. 155-161. Tokyo: Society of Fermentation Technology.

Kato, N., Nishizawa, T., Sakazawa, C., Tani, Y. \& Yamada, H. (1979). Xylulose 5-phosphate-dependent fixation of formaldehyde in a methanolutilizing yeast, Kloeckera sp. 2201. Agricultural and Biological Chemistry 43, 2013-2015.

LAW, A. T. \& BuTTON, D. K. (1977). Multiple-carbon source limited growth kinetics of a marine coryneform bacterium. Journal of Bacteriology 129, $115-$ 123.

Law, A. T., Robertson, B. R., Dunker, S. S. \& Butron, D. K. (1976). On describing microbial growth kinetics from continuous culture data: some general considerations, observations and concepts. Microbial Ecology 2, 261-283.

LEE, J.-D. \& Komagata, K. (1980). Taxonomic study of methanol-assimilating yeasts. Journal of General and Applied Microbiology 26, 133-158.

Lindley, N. D., Waites, M. J. \& QuayLe, J. R. (1980).
A modified pulse-labelling technique for the detection of early intermediates in microbial metabolism: detection of $\left[{ }^{1+} \mathrm{C}\right]$ dihydroxyacetone during assimilation of $\left[{ }^{14} \mathrm{C}\right]$ methanol by Hansenula polymorpha. FEMS Microbiology Letters 8, 13-16.

VON MEYenburG, K. (1969). Katabolit-Repression und der Sprossungszyklus von Saccharomyces cerevisiae. Dissertation no. 4279 , ETH, Zürich, Switzerland.

NG, F. M.-W. \& Dawes, E. A. (1973). Chemostat studies on the regulation of glucose metabolism in Pseudomonas aeruginosa by citrate. Biochemical Journal 132, 129-140.

O'Connor, M. \& Quayle, J. R. (1979). Mutants of Hansenula polvmorpha and Candida boidinit impaired in their ability to grow on methanol. Journal of General Microbiology 113, 203-208.

Powell, E. O. (1967). The growth rate of microorganisms as a function of substrate concentration. In Microbial Physiology and Continuous Culture. Proceedings of the 3rd International Symposium on Continuous Culture of Microorganisms, pp. 34-55. Edited by E. O. Powell, C. G. T. Evans, R. E. Strange \& D. W. Tempest. London: H.M.S.O

Ratledge, C. \& Botham, P. A. (1977), Pathways of glucose metabolism in Candida 107, a lipid-accumulating yeast. Journal of General Microbiology 102, 391-395.

RITTENBERG, S. C. (1972). The obligate autotroph - the demise of a concept. Antonie van Leeuwenhoek 38, 457-478.

Schlegel, H. G. (1981). Allgemeine Mikrobiologie, p. 223. Stuttgart: Georg Thieme Verlag.

TCHOLA, O. \& HoRECKER, B. L. (1966). Transaldolase. Methods in Enzymology 9, 499-505.

Waites, M. J. \& QuAYle, J. R. (1980). Dihydroxyacetone: a product of xylulose 5-phosphate-dependent fixation of formaldehyde by methanol-grown Candida boidinii. Journal of General Microbiology 118 , $321-327$

Waites, M. J. \& QuaYle, J. R. (1981). The interrelation between transketolase and dihydroxyacetone synthase activities in the methylotrophic yeast Candida boidinii. Journal of General Microbiology 124, 309-316

Waites, M. J. \& Quayle, J. R. (1983). Dihydroxyacetone synthase: a special transketolase for formaldehyde fixation from the methylotrophic yeast Candida boidinii CBS 5777. Journal of General Microbiology 129, 935-944.

Waites, M. J., Lindley, N. D. \& Quayle, J. R. (1981). Determination of the labelling pattern of dihydroxyacetone and hexose phosphate following a brief incubation of methanol-grown Hansenula polymorpha with $\left[{ }^{1+} \mathrm{C}\right]$ methanol. Journal of General Microbiology 122, 193-199.

WoOD, T. (1970). Spectrophotometric assay for Dribose-5-phosphate ketol-isomerase and for D-ribulose-5-phosphate 3-epimerase. Analytical Biochemistry 33, 297-306. 